\title{
Gender differences in job separation rates and employment stability: New evidence from employer-employee data ${ }^{\grave{3}}$
}

\author{
Anders Frederiksen * \\ Hoover Institution, Stanford University; Aarhus School of Business, Aarhus University and IZA
}

Received 9 August 2006; received in revised form 22 May 2007; accepted 21 July 2007

Available online 3 August 2007

\begin{abstract}
I analyze the job separation process to learn about gender differences in job separation rates and employment stability. An essential finding is that employer-employee data are required to identify gender differences in job separation probabilities because of labor market segregation. Failure to recognize this may potentially lead to statistical discrimination. Three important empirical results are obtained from the analysis. First, women have higher unconditional job separation probabilities. Second, there are no gender differences in job separation probabilities for employees working in similar workplaces. Finally, women's employment stability is relatively low because they are more likely to move from a job and into unemployment or out of the labor force, and less likely to make job-to-job transitions.
\end{abstract}

(C) 2007 Elsevier B.V. All rights reserved.

JEL classification: C23; E24; J63

Keywords: Job separations; Employment stability; Labor reallocation; Employer-employee data

\footnotetext{
I I thank Torben M. Andersen, Patricia M. Anderson, Orley Ashenfelter, Paul Bingley, Nabanita Datta Gupta, Hank Farber, Bo Honoré, John Pencavel, Felix Reichling, Kathryn Shaw and Niels Westergaard-Nielsen for valuable discussions and comments. I am also thankful for the comments given by seminar and conference participants at Princeton University, the Aarhus School of Business, Center for Corporate Performance, CAED'03, Panel'11, and the IZA and Upjohn conference on employee reallocation in Kalamazoo. This paper was written during my visit at the Industrial Relations Section at Princeton University. The research project has been supported financially by the Danish Social Science Research Council through a grant given to the Center for Corporate Performance (CCP). Anders Aagaard has provided valuable research assistance.

* Mailing address: Department of Economics, Aarhus School of Business, Silkeborgvej 2, DK-8000 Aarhus C, Denmark. Tel.: +45 89486396 .

E-mail address: Afr@asb.dk
}

0927-5371/\$ - see front matter (C) 2007 Elsevier B.V. All rights reserved.

doi:10.1016/j.labeco.2007.07.010 


\section{Introduction}

Employee turnover has been documented to be high in most countries, see Davis, Haltiwanger and Schuh (1996) and Davis and Haltiwanger (1999). Even though it is no surprise that a substantial part of the workforce leaves their workplaces every year, it is not a simple task to pinpoint the employees who are most likely to leave, and the workplaces from which employees are likely to separate. Improved knowledge about the job separation decision is important for employers in order to make workforce adjustments and develop retention policies that impose minimal disruption to the production process. Employees also benefit from this information because it allows them to make informed choices about where to work. More generally, this knowledge will help shape public policy targeting employment stability.

The primary goal of the analysis is to study the job separation process with the purpose of answering two important questions. First, do men and women who experience similar working conditions have different job separation rates? Second, does employment stability differ for men and women? Previous studies of job separation processes have provided some insights into these questions, but data limitations have restricted their focus to information on individuals or workplaces. For instance, studies focusing on the individual component have documented the effects of human capital and demographic variables on the probability that an employee separates from the job (Blau and Kahn, 1981; Light and Ureta, 1992; Lynch, 1992; Royalty, 1998). Parallel to these studies, Anderson and Meyer (1994) have analyzed how workplace characteristics influence the job separation probability. In this study, I will integrate these two lines of research using a register-based employer-employee data set.

Identification of gender differences in job separation rates is infeasible without simultaneous information about employees and workplaces because of labor market sorting. Sorting takes place when matches between employees and workplaces are non-random, i.e., employees make directed search when looking for a job, and employers are selective in their choice of workforce. The sorting process will naturally lead to a segregated labor market where distinct groups of individuals work in different types of workplaces. ${ }^{1}$ Empirically, I find the tendency that women work in smaller low-wage workplaces with relatively high levels of job separations. ${ }^{2}$ In the analysis conducted below, I show that failure to recognize this labor market segregation will lead to biased estimates and incorrect conclusions about gender differences in job separation probabilities, which potentially leads to statistical discrimination. Furthermore, I argue that conventional statistical methods, such as the random-effects or fixed-effects models, are unable to eliminate the bias induced by omitted variables when the labor market is segregated. Instead, consistent estimates can successfully be obtained from employer-employee data.

The focus on gender differences provides a series of important empirical results. First, women have higher unconditional job separation rates than men. Women's separation rates are also estimated to be significantly higher conditional on a large set of individual characteristics. Taking these findings at face value, women will face statistical discrimination in the labor market. This result arises because labor market segregation is ignored. Thus, heterogeneity in job separation rates across workplaces due to differences in workplace characteristics are picked up by individual characteristics leading to biases. A more comprehensive analysis of the employer-

\footnotetext{
${ }^{1}$ Macpherson and Hirsch (1995) discuss theories hypothesizing about reasons for gender segregation. They point at past and current discrimination as well as differences in preferences as potential explanations. Empirical studies, such as Gupta (1993) and Padavic (1992), provide empirical evidence for these hypotheses. I continue this discussion below.

2 This is consistent with recent findings in Bayard et al. (2003).
} 
employee data shows that adding information about the workplace, such as the size of the workplace and the payroll class, has the consequence that the gender coefficient becomes insignificant. Hence, there are no significant gender differences in the job separation rates for employees working in similar workplaces. ${ }^{3}$ If employers recognize this result, statistical discrimination due to gender based on concerns about costly job separations should be absent from the labor market.

The fact that gender is an insignificant predictor for job separations conditional on working conditions does not imply that men and women experience the same employment stability. The main reason for this is that the stability of employment matches and the employee's destination state subsequent to a job separation vary due to differences in both workplace and employee characteristics. This implies that the employment prospects may differ substantially for men and women in a gender-segregated labor market. To address this issue further, I estimate a multinomial logit model using information about the destination states following an employment match. The parameters from this regression are used to predict the labor market outcomes for the population of individuals currently working. The key results are that currently employed women relative to employed men are more likely to separate from a job (two percentage-points), experience a spell of unemployment and withdraw from the labor market. In addition, they are less likely to make jobto-job transitions. Hence, women's employment stability is clearly below men's.

A decomposition of the two percentage-points gap in job separation rates reveals that 25 percent can be contributed to differences in individual characteristics and the remaining 75 percent to differences in the workplace component. These results emphasize that future labor market policies intended to equalize employment stability between men and women should focus not only on removing gender differences in individual characteristics, such as education levels, but also have considerable focus on eliminating differences in workplace characteristics, i.e., to reduce labor market segregation.

The data used in the analysis is the Integrated Database for Labor Market Research (IDA). The database contains information on all employees from all establishments in all sectors in Denmark in the years 1980 to 2000. Each year (on a specific day in November) all employees and workplaces are merged, providing a snapshot of all employment matches in the Danish economy. Further, employees and workplaces carry unique identification numbers which enable tracking over time. Thus, the data provides a unique opportunity to study mobility patterns in the labor market. In the following analysis I focus on a sub-sample containing all private sector workplaces and their employees, corresponding to 3,253,312 unique employees and 477,619 workplaces, or $29,069,419$ November-employment matches over the 20 -year period. ${ }^{4}$

The Danish labor market shares many of the characteristics found in the UK and US labor markets. For example, all three countries have highly liberal labor market policies. However, they differ in one respect, namely in the generosity of unemployment benefit levels. To the interested reader Appendix A provides a detailed discussion of the institutional settings in Denmark and a comparison with the labor markets in the US and the UK.

In the next section I present descriptive statistics of the data used in the analysis. Two points are made in this section. First, the level of job separations is high. Second, men and women are

\footnotetext{
${ }^{3}$ Sicherman (1996) studies the separation process using data from a single workplace. He finds that the overall separation rates are similar for men and women, but the reason for quitting differs across gender. Similarly, Weiss (1984) finds no gender differences in the separation rates in his stylized model, which is estimated from a data set based on a sample of newly hired semiskilled production employees at two manufacturing facilities. These results match well with the more general findings presented in this paper.

${ }^{4}$ The data are documented on http:/www.asb.dk/research/centresteams/centres/ccp/ccpresearch/databases/ida.aspx.
} 


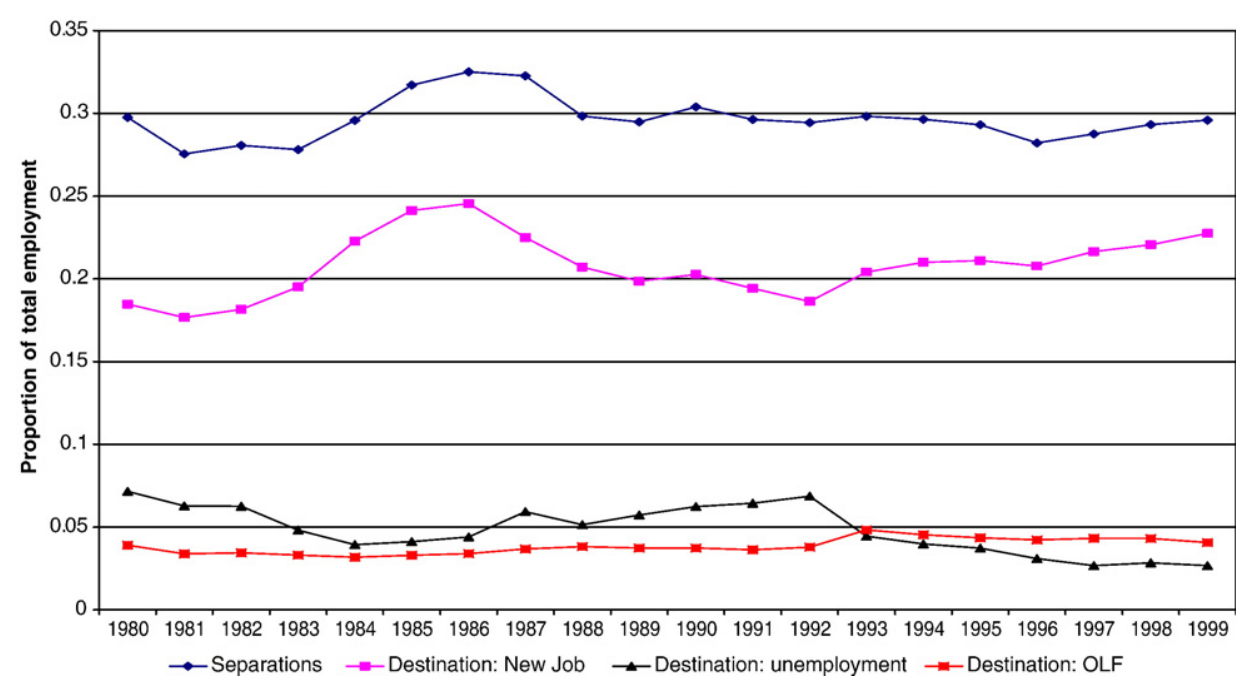

Fig. 1. Level of individual job separations and associated destination states, 1980-2000.

somewhat segregated in the labor market in the sense that women tend to be employed in smaller low-paying workplaces with relatively higher turnover. The latter plays an important role for the empirical findings in this paper. The theoretical framework for modeling the job separation process and associated labor market flows is presented in Section 3, and the estimation strategy is proposed in Section 4. In Section 5 I discuss and illustrate the empirical consequences for the job separation process when important variables are omitted, and the labor market is segregated. This analysis is extended in Section 6 to include information on the individual's destination states. The extended framework is used to advance our knowledge of gender differences in job separation rates and employment stability. The results an policy implications are discussed in Section 7. Section 8 concludes the paper.

\section{Individual job separations and labor market flows}

The importance of understanding the job separation process is illustrated in Fig. 1, which presents the level of job separations and associated labor market flows for the years 1980 to 2000 . The level of job separations was between 27 and 32 percent in any given year with an average of 29.53 percent. In other words, more than 300,000 employees out of the private sector labor force of 1,250,000 leave their jobs each year. Of these, around 70 percent make job-to-job transitions, and the remaining separations are split almost equally between transitions into unemployment and out of the labor force. ${ }^{5}$ In an international context these numbers are large and comparable to findings in the United Kingdom and the United States, see Davis, Haltiwanger and Schuh (1996).

Table 1 presents the descriptive statistics for the employees making the flows shown in Fig. 1. On average, the employees are 36.5 years old and have 11.6 years of education. ${ }^{6}$ A little more

\footnotetext{
${ }^{5}$ For further details, see Frederiksen and Westergaard-Nielsen (in press), who provide a detailed analysis of employee behavior subsequent to a job separation.

${ }^{6}$ Compulsory education in Denmark is 9 years (extended from 7 to 9 years in 1964), and 12 years of education correspond to the completion of high school.
} 
Table 1

Descriptive statistics for individuals and workplaces, 1980 to 2000

\begin{tabular}{|c|c|c|c|}
\hline & Women & Men & All \\
\hline Job separation probability & 0.308 & 0.288 & 0.295 \\
\hline \multicolumn{4}{|l|}{ Individual characteristics: } \\
\hline Women $(=1)$ & - & - & $\begin{array}{l}0.38 \\
(0.48)\end{array}$ \\
\hline Age & $\begin{array}{l}36.01 \\
(12.12)\end{array}$ & $\begin{array}{l}36.94 \\
(12.12)\end{array}$ & $\begin{array}{l}36.59 \\
(12.12)\end{array}$ \\
\hline Cohabitating/married & $\begin{array}{l}0.53 \\
(0.50)\end{array}$ & $\begin{array}{l}0.53 \\
(0.50)\end{array}$ & $\begin{array}{l}0.53 \\
(0.50)\end{array}$ \\
\hline Children & $\begin{array}{l}0.65 \\
(0.90)\end{array}$ & $\begin{array}{l}0.66 \\
(0.94)\end{array}$ & $\begin{array}{l}0.66 \\
(0.93)\end{array}$ \\
\hline Education (years) & $\begin{array}{l}11.24 \\
(2.59)\end{array}$ & $\begin{array}{l}11.81 \\
(2.78)\end{array}$ & $\begin{array}{l}11.60 \\
(2.72)\end{array}$ \\
\hline Proportion of new hires & 0.32 & 0.30 & 0.31 \\
\hline \multicolumn{4}{|l|}{ Workplace characteristics: } \\
\hline \# Employees & $\begin{array}{l}227.36 \\
(681.86)\end{array}$ & $\begin{array}{l}267.88 \\
(769.60)\end{array}$ & $\begin{array}{l}252.56 \\
(737.91)\end{array}$ \\
\hline Payroll per employee in DKK & $\begin{array}{l}131,696 \\
(72,428)\end{array}$ & $\begin{array}{l}150,686 \\
(70,197)\end{array}$ & $\begin{array}{l}143,506 \\
(71,643)\end{array}$ \\
\hline \# Observations & $10,390,062$ & $16,952,207$ & $27,342,269$ \\
\hline
\end{tabular}

Note: Standard errors are in parentheses.

than half of the individuals are married, and they have 0.66 children on average. There are some differences between the characteristics of men and women, but in general these are small. Most pronounced are the differences in education and age, where men are found to be one year older on average and have almost half a year more education. A different picture emerges if we look at the employee-weighted workplace characteristics. The average payroll per employee is DKK $143,506(\approx € 20.000)$, and the workplace size is 253 people. The corresponding numbers for men and women separately show that men are employed in larger workplaces, with a payroll per employee that is almost 15 percent higher on average. Combining this with the fact that the correlation between women and workplace size is -0.03 , and the correlation between women and payroll per employee is -0.13 suggests that men and women tend to work in segregated labor markets.

\section{Modeling the job separation process}

In this section a standard model of job separations and labor market flows is presented. The value of the employment match is a function of the individual's characteristics and working conditions, i.e., workplace size, the incentive scheme, etc. Let the value of the match between individual $i$ and the workplace where she is currently employed be characterized by the function:

$$
V_{i t}^{C}=V\left(X_{i t}, Z_{i t}, \varepsilon_{i t}^{C}\right)
$$

where $X=\{$ set of observable time-varying individual characteristics $\}, Z=\{$ set of observable time-varying workplace characteristics $\}$, and $\varepsilon$ is a stochastic term reflecting that the value of 
the match is known only with uncertainty. ${ }^{7}$ Thus, $\mathrm{X}$ and $\mathrm{Z}$ contain all relevant information about the employment match. ${ }^{8}$ As an alternative to current employment, the individual may have the option to work for an alternative employer (A). Two considerations are required when describing the match value of alternative employment. First, the alternative workplace may value the characteristics of the employee differently from the current workplace. Second, the characteristics of the alternative workplace are likely to differ form the characteristics of the current workplace and are generally unobservable (to the researcher). This implies that the value function describing the match between the alternative workplace and the employee is different from the value function characterizing the current match. Thus, I write the characteristics of the alternative workplace as a function of the characteristics of the current workplace, i.e., $Z_{i t}^{A}=Z_{i t}^{\prime} \eta$. It follows that the value of the match between the employee and the alternative workplace is:

$$
V_{i t}^{A}=V^{A}\left(X_{i t}, Z_{i t}{ }^{\prime} \eta, \varepsilon_{i t}^{A}\right) .
$$

The employee has initially chosen to work for the current workplace, meaning that the value of current employment must exceed the value of employment in an alternative workplace. Hence, the condition $V_{i t}^{C}-V_{i t}^{A}>0$ must necessarily be satisfied. However, changes in future periods (referred to by $\mathrm{k}>0$ ) in any of the components of $\Pi=\left\{X_{i t+k}, Z_{i t+k}, Z_{i t+k}^{A}, \varepsilon_{i t+k}, \varepsilon_{i t+k}^{A}\right\}$ may potentially reverse the inequality, making it more beneficial for the employee to leave the current workplace. Given a separation, the individual is likely to move to an alternative employer, i.e., $V_{i t+k}^{A}>V_{i t+k}^{C}$, but in some cases the incentive to work vanishes. This latter case characterizes the situation where demand is absent (wages are too low), but it also reflects the situation where the characteristics of the employee develop such that the opportunity costs of working exceed the value of work. In both situations the destination state of the employee will depend upon the relative ranking of the value of unemployment, $V_{i t}^{U}$, and the value of leaving the labor force, $V_{i t}^{O L F}$. Denoting the outcome of the decision by $y$, the transition probabilities can be given the following representation:

$$
\begin{aligned}
& \operatorname{Pr}\left(y_{i, t}=C\right)=\operatorname{Pr}\left(V_{i t}^{C} \geq V_{i t}^{A}, V_{i t}^{C} \geq V_{i t}^{U}, V_{i t}^{C} \geq V_{i t}^{O L F}\right) \\
& \operatorname{Pr}\left(y_{i, t}=A\right)=\operatorname{Pr}\left(V_{i t}^{A}>V_{i t}^{C}, V_{i t}^{A} \geq V_{i t}^{U}, V_{i t}^{A} \geq V_{i t}^{O L F}\right) \\
& \operatorname{Pr}\left(y_{i, t}=U\right)=\operatorname{Pr}\left(V_{i t}^{U}>V_{i t}^{C}, V_{i t}^{U}>V_{i t}^{A}, V_{i t}^{U} \geq V_{i t}^{O L F}\right) \\
& \operatorname{Pr}\left(y_{i, t}=O L F\right)=\operatorname{Pr}\left(V_{i t}^{O L F}>V_{i t}^{C}, V_{i t}^{O L F}>V_{i t}^{A}, V_{i t}^{O L F}>V_{i t}^{U}\right)
\end{aligned}
$$

The above system of equations will form the basis for estimation in the next section.

\footnotetext{
${ }^{7}$ Superscripts refer to destination states, i.e., C refers to current employer, A to alternative employer, U to unemployment and OLF to out of the labor force.

${ }^{8}$ A natural extension of the present model, which is beyond the scope of this paper, is to address the consequences of asymmetric and imperfect information about employer or employee characteristics for the job separation process. These ideas date back to Jovanovic (1979), Spence (1973) and Holmström (1979) and have recently been addressed by Frederiksen and Takàts (2006).
} 


\section{Estimation}

The multinomial logit accounts for the components of the theoretical model outlined above. Let individual $i$ with characteristics $X_{i t}$, who works in a workplace with characteristics $Z_{i t}$ at time $t$ face the choice set $M=\{C, A, U, O L F\}$. Given appropriate assumptions about the stochastic terms in the value functions, the empirical transition probability associated with each state for individual $i$ at time $t$ is:

$$
\begin{aligned}
& \operatorname{Pr}\left(y_{i t}=j \mid X_{i t}, Z_{i t}, \theta\right)=\frac{\exp \left(X_{i t}{ }^{\prime} \beta_{j}+Z_{i t}{ }^{\prime} \gamma_{j}\right)}{1+\sum_{j \in\{C, U, O L F\}} \exp \left(X_{i t}{ }^{\prime} \beta_{j}+Z_{i t}{ }^{\prime} \gamma_{j}\right)}, j=C, U, O L F \\
& \operatorname{Pr}\left(y_{i t}=j \mid X_{i t}, Z_{i t}, \theta\right)=\frac{1}{1+\sum_{j \in\{C, U, O L F\}} \exp \left(X_{i t}{ }^{\prime} \beta_{j}+Z_{i t}{ }^{\prime} \gamma_{j}\right)}, j=A,
\end{aligned}
$$

where $\beta_{A} \eta$ and $\gamma_{A} \eta$ (the parameters of the reference category, $j=A$ ) are normalized to zero for identification purposes, and $\theta=\left\{\beta_{j}, \gamma_{j}\right\}$. The individual contribution to the likelihood can be constructed from the empirical probabilities:

$$
\begin{aligned}
& L_{i}\left(\theta \mid y_{i 1}, y_{i 2}, \ldots, y_{i T}, X_{i 1}, X_{i 2}, \ldots, X_{i T}, Z_{i 1}, Z_{i 2}, \ldots, Z_{i T}\right) \\
& \quad=\prod_{t=1}^{T} \sum_{j=M} \operatorname{Pr}\left(y_{i t} \mid X_{i t}, Z_{i t}, \theta\right) 1_{\left(y_{i t}=j\right)} .
\end{aligned}
$$

Taking the product over all individuals, the full likelihood function becomes:

$$
\begin{aligned}
& L\left(\theta \mid y_{i 1}, y_{i 2}, \ldots, y_{i T}, X_{i 1}, X_{i 2}, \ldots, X_{i T}, Z_{i 1}, Z_{i 2}, \ldots, Z_{i T}\right) \\
& \quad=\prod_{i=1}^{N} L_{i}\left(\theta \mid y_{i 1}, y_{i 2}, \ldots, y_{i T}, X_{i 1}, X_{i 2}, \ldots, X_{i T}, Z_{i 1}, Z_{i 2}, \ldots, Z_{i T}\right) .
\end{aligned}
$$

This likelihood can be maximized using conventional methods, and consistent estimates of the parameters $\theta$ can be obtained. Note that the logit model is closely related to the multinomial logit model, but having $M=\{C, S e p\}$ where $\operatorname{Sep}=\{A \cup U \cup O L F\}$, i.e., the individual has the choice between staying with the current workplace and separating. This observation is interesting because the logit model has formed the basis for most previous studies of job separations processes and will be the subject of study in the next section.

\section{Empirical consequences of omitted variables in a segregated labor market}

Previous studies of job separation processes have omitted either the workplace or the individual component from the empirical analysis due to data limitations. The evidence on labor market segregation presented in Section 2 (the correlation between the individual and the workplace components) suggests that this may be a serious problem. To address this issue further, this section illustrates the empirical consequences of omitted variables in the presence of labor market sorting. 
To focus the discussion, consider the binary choice model for the job separation decision:

$$
y_{i, t}=1\left(X_{i t}^{\prime} \beta+Z_{i t}^{\prime} \gamma+\varepsilon_{i t} \geq 0\right),
$$

where $\beta$ and $\gamma$ are the parameters of interest, and $\varepsilon$ has a standard logistic distribution. In general, $\operatorname{corr}(X, Z) \neq 0$. If $X$ and $Z$ are observable, then $\beta$ and $\gamma$ can be estimated by maximum likelihood. However, most studies of the separation process suffer from omitted variables due to data limitations, and in general either $\mathrm{X}$ or $\mathrm{Z}$ is unobservable to the researcher.

The model to be estimated in the absence of information on $\mathrm{Z}$ is: ${ }^{9}$

$$
y_{i, t}=1\left(X_{i t}^{\prime} \beta+v_{i t} \geq 0\right),
$$

where $v=Z_{i t}^{\prime} \gamma+\varepsilon, E v=0$, and $\operatorname{var}(v)=\operatorname{var}\left(Z_{i t}^{\prime} \gamma\right)+\operatorname{var}(\varepsilon)$ because $\varepsilon \perp Z_{i t}^{\prime} \gamma$. Estimation of $\beta$ in model (4) is problematic unless we are willing to impose assumptions on the structure of the omitted variables. One example of an econometric solution to the omitted variable problem is the random-effects model. This model relies on the assumption that the omitted variables follow some distribution and are uncorrelated with any of the included explanatory variables. An alternative is the fixed-effects model, which allows for correlation between the included and the omitted variables, but requires that the omitted component degenerates into one time-invariant point. Both of these approaches are problematic within the present context. The reason is that the data shows a positive correlation between being a woman and working in a smaller low-wage workplace which implies that $\operatorname{corr}\left(X_{i t}, Z_{i t}\right) \neq 0$. Further, both the individual and workplace characteristics are time-varying due to the fact that employees become older and workplaces expand or decline. This combined suggest that there are potential empirical problems associated with estimation of the job separation process if information on the individual and workplace components are not included simultaneously. ${ }^{10}$ Below I show that these concerns have empirical relevance.

The first step in the empirical analysis is to replicate two existing studies by Anderson and Meyer (1994) and Royalty (1998) in as much detail as possible. Hence, the variables included in these initial regressions are determined by their work. ${ }^{11}$ The first model considered includes information about the payroll class and the workplace size together with a dummy for being a recently hired employee. These variables are intended to represent the employee's working conditions and to capture bad initial matches. The second model includes a large set of employee characteristics but contains no information about the workplace. To account for labor market segregation and eliminate potential omitted variable biases, the second step in the analysis is to introduce the full battery of employer and employee characteristics and evaluate the consequences for the empirical results. ${ }^{12}$

The results presented in Table 2 indicate that the effects of working conditions are stable across models. For instance, a low payroll class leads to more frequent separations, unconditional on

\footnotetext{
9 The case where information on $\mathrm{X}$ is omitted can be treated symmetrically.

${ }^{10}$ See Frederiksen et al. (in press) for a continuation of this discussion.

${ }^{11} \mathrm{I}$ am able to replicate the Anderson and Meyer regressions specification in terms of explanatory variables (model 1). I lack information on some of the variables included in Royalty's analysis (model 2). But I approximate her analysis by including a large set of explanatory variables characterizing the individual.

12 Predicting the outcome from the three models reveals that model 2 is better at generating the variation in the dependent variable relative to model 1 (standard deviation of 0.1384 vs. 0.1296). Combining the two models drives the standard deviation up to 0.1471 . This is to be compared to an empirical standard deviation of 0.2085 .
} 
Table 2

Logit models for individual job separations (yearly)

\begin{tabular}{|c|c|c|c|}
\hline & Model 1 & Model 2 & Model 3 \\
\hline Constant & $\begin{array}{c}-\mathbf{0 . 0 5 5} \\
(0.026)\end{array}$ & $\begin{array}{l}\mathbf{1 . 7 6 2} \\
(0.029)\end{array}$ & $\begin{array}{l}\mathbf{2 . 0 5 1} \\
(0.030)\end{array}$ \\
\hline \multicolumn{4}{|l|}{ Individual characteristics } \\
\hline Women & & $\begin{array}{l}\mathbf{0 . 0 6 6} \\
(0.003)\end{array}$ & $\begin{array}{l}0.001 \\
(0.003)\end{array}$ \\
\hline Age/10 & & $\begin{array}{l}-\mathbf{1 . 4 7 2} \\
(0.009)\end{array}$ & $\begin{array}{c}-\mathbf{1 . 2 6 8} \\
(0.009)\end{array}$ \\
\hline Age squared/100 & & $\begin{array}{l}\mathbf{0 . 1 6 7} \\
(0.001)\end{array}$ & $\begin{array}{l}\mathbf{0 . 1 4 3} \\
(0.001)\end{array}$ \\
\hline Married & & $\begin{array}{l}-\mathbf{0 . 1 7 9} \\
(0.004)\end{array}$ & $\begin{array}{c}-\mathbf{0 . 1 9 4} \\
(0.004)\end{array}$ \\
\hline Children & & $\begin{array}{l}\mathbf{0 . 0 1 0} \\
(0.004)\end{array}$ & $\begin{array}{l}-0.001 \\
(0.004)\end{array}$ \\
\hline Education $<12$ years & & - & - \\
\hline Education $12-16$ years & & $\begin{array}{c}-\mathbf{0 . 0 6 9} \\
(0.003)\end{array}$ & $\begin{array}{l}-0.006 \\
(0.003)\end{array}$ \\
\hline Education $>16$ years & & $\begin{array}{c}-\mathbf{0 . 1 2 1} \\
(0.008)\end{array}$ & $\begin{array}{l}-0.001 \\
(0.008)\end{array}$ \\
\hline New hire dummy (Tenure $<2$ years) & $\begin{array}{l}\mathbf{0 . 9 3 9} \\
(0.003)\end{array}$ & $\begin{array}{l}\mathbf{0 . 8 8 4} \\
(0.003)\end{array}$ & $\begin{array}{l}\mathbf{0 . 8 1 4} \\
(0.003)\end{array}$ \\
\hline \multicolumn{4}{|l|}{ Workplace characteristics } \\
\hline Payroll < DKK 50 thousand & - & & - \\
\hline Payroll DKK 50-100 thousand & $\begin{array}{c}-\mathbf{0 . 5 6 1} \\
(0.006)\end{array}$ & & $\begin{array}{c}-\mathbf{0 . 5 0 3} \\
(0.006)\end{array}$ \\
\hline Payroll DKK 100-150 thousand & $\begin{array}{c}-\mathbf{0 . 9 1 4} \\
(0.006)\end{array}$ & & $\begin{array}{c}-\mathbf{0 . 7 8 7} \\
(0.006)\end{array}$ \\
\hline Payroll DKK 150-200 thousand & $\begin{array}{c}-\mathbf{1 . 1 0 3} \\
(0.006)\end{array}$ & & $\begin{array}{c}-\mathbf{0 . 9 3 4} \\
(0.007)\end{array}$ \\
\hline Payroll > DKK 200 thousand & $\begin{array}{c}-\mathbf{1 . 1 8 8} \\
(0.007)\end{array}$ & & $\begin{array}{l}-\mathbf{0 . 9 6 6} \\
(0.007)\end{array}$ \\
\hline Workplace size $<20$ employees & - & & - \\
\hline Workplace size $20-99$ employees & $\begin{array}{l}\mathbf{0 . 0 1 2} \\
(0.004)\end{array}$ & & $\begin{array}{l}\mathbf{0 . 0 1 6} \\
(0.004)\end{array}$ \\
\hline Workplace size 100-499 employees & $\begin{array}{l}0.004 \\
(0.004)\end{array}$ & & $\begin{array}{l}\mathbf{0 . 0 2 0} \\
(0.004)\end{array}$ \\
\hline Workplace size $>500$ employees & $\begin{array}{c}-\mathbf{0 . 1 0 3} \\
(0.005)\end{array}$ & & $\begin{array}{l}-\mathbf{0 . 0 9 9} \\
(0.006)\end{array}$ \\
\hline Industry controls & Yes & Yes & Yes \\
\hline Unemployment rate controls & Yes & Yes & Yes \\
\hline Mean log likelihood & -0.5685 & -0.5628 & -0.5570 \\
\hline
\end{tabular}

Note: Estimation is made on a 10 percent random sample of individual employment histories. The number of observations is $2,613,454$.

employee characteristics. This is not the case for the individual component. Of particular interest is the change of the gender coefficient from significant to insignificant between models 2 and 3 . This is a remarkable result because the large sample size allows for identification of even very 
Table 3

Logit models for individual job separations (yearly)

\begin{tabular}{|c|c|c|}
\hline & Women & Men \\
\hline Constant & $\begin{array}{l}\mathbf{2 . 5 4 7} \\
(0.048)\end{array}$ & $\begin{array}{l}\mathbf{1 . 0 8 1} \\
(0.011)\end{array}$ \\
\hline \multicolumn{3}{|l|}{ Individual characteristics } \\
\hline Age/10 & $\begin{array}{c}-\mathbf{1 . 5 6 6} \\
(0.015)\end{array}$ & $\begin{array}{c}-\mathbf{1 . 0 8 1} \\
(0.011)\end{array}$ \\
\hline Age squared/100 & $\begin{array}{l}\mathbf{0 . 1 7 6} \\
(0.002)\end{array}$ & $\begin{array}{l}\mathbf{0 . 1 2 3} \\
(0.001)\end{array}$ \\
\hline Married & $\begin{array}{c}-\mathbf{0 . 1 9 9} \\
(0.006)\end{array}$ & $\begin{array}{l}-\mathbf{0 . 1 8 4} \\
(0.005)\end{array}$ \\
\hline Children & $\begin{array}{l}\mathbf{0 . 0 8 3} \\
(0.006)\end{array}$ & $\begin{array}{l}-\mathbf{0 . 0 6 2} \\
(0.005)\end{array}$ \\
\hline Education $<12$ years & - & - \\
\hline Education $12-16$ years & $\begin{array}{c}-\mathbf{0 . 0 4 3} \\
(0.005)\end{array}$ & $\begin{array}{l}\mathbf{0 . 0 1 1} \\
(0.004)\end{array}$ \\
\hline Education $>16$ years & $\begin{array}{l}0.003 \\
(0.013)\end{array}$ & $\begin{array}{l}-0.012 \\
(0.010)\end{array}$ \\
\hline New hire dummy (tenure $<2$ years) & $\begin{array}{l}\mathbf{0 . 7 3 1} \\
(0.005)\end{array}$ & $\begin{array}{l}\mathbf{0 . 8 5 9} \\
(0.004)\end{array}$ \\
\hline \multicolumn{3}{|l|}{ Workplace characteristics } \\
\hline Payroll < DKK 50 thousand & - & - \\
\hline Payroll DKK 50-100 thousand & $\begin{array}{c}-\mathbf{0 . 4 8 8} \\
(0.008)\end{array}$ & $\begin{array}{c}-\mathbf{0 . 5 1 3} \\
(0.009)\end{array}$ \\
\hline Payroll DKK 100-150 thousand & $\begin{array}{c}-\mathbf{0 . 7 6 1} \\
(0.009)\end{array}$ & $\begin{array}{l}-\mathbf{0 . 8 0 1} \\
(0.009)\end{array}$ \\
\hline Payroll DKK 150-200 thousand & $\begin{array}{c}-\mathbf{0 . 9 1 4} \\
(0.010)\end{array}$ & $\begin{array}{c}-\mathbf{0 . 9 4 4} \\
(0.009)\end{array}$ \\
\hline Payroll > DKK 200 thousand & $\begin{array}{c}-\mathbf{0 . 8 8 7} \\
(0.010)\end{array}$ & $\begin{array}{l}-1.001 \\
(0.010)\end{array}$ \\
\hline Workplace size $<20$ employees & - & - \\
\hline Workplace size 20-99 employees & $\begin{array}{l}0.005 \\
(0.006)\end{array}$ & $\begin{array}{l}\mathbf{0 . 0 2 1} \\
(0.005)\end{array}$ \\
\hline Workplace size 100-499 employees & $\begin{array}{c}-\mathbf{0 . 0 1 5} \\
(0.007)\end{array}$ & $\begin{array}{l}\mathbf{0 . 0 3 8} \\
(0.006)\end{array}$ \\
\hline Workplace size $>500$ employees & $\begin{array}{c}-\mathbf{0 . 0 8 6} \\
(0.009)\end{array}$ & $\begin{array}{l}-\mathbf{0 . 1 0 5} \\
(0.007)\end{array}$ \\
\hline Industry controls & Yes & Yes \\
\hline Unemployment rate controls & Yes & Yes \\
\hline \# Observations & 991,279 & $1,622,175$ \\
\hline
\end{tabular}

Note: Estimation is made on a 10 percent random sample of individual employment histories.

small differences. ${ }^{13}$ Also, the effect of education is reduced to insignificance. Thus, these regressions clearly show the importance of using employer-employee data when studying the job separation process because labor market segregation makes the results sensitive to omitted

\footnotetext{
${ }^{13}$ Introducing the workplace variables sequentially reveals that payroll class has the largest effect on the individual characteristics. Thus, it is the main driving force behind the changes from significance to insignificance in the gender and education coefficients.
} 
variables. In fact, the correlations between included and omitted variables in model 2 are sufficiently strong to change the results when they are included simultaneously. ${ }^{14}$

In addition to providing a vital econometric result, Table 2 sends an important economic message. The results from model 2 lead to the conclusion that women have a higher job separation probability than men. This result arises, however, because labor market segregation has been ignored. In other words, it is not taken into account that women tend to work in smaller low-paying workplaces, which in general experience higher job separation rates. Thus, omitting workplace characteristics from the analysis contributes variation in firm behavior to gender and causes an upward bias in the gender dummy. For this reason, it is important to stress the result of model 3 that there is no significant difference in the job separation rates between men and women once working conditions are taken into account. Failure to recognize this point may lead to statistical gender discrimination.

Having established the importance of including both individual and workplace components simultaneously in the analysis of job separations, I move on to estimate separate models for men and women, see Table 3. This is motivated by the studies by Blau and Kahn (1981), Light and Ureta (1992), Lynch (1992), and Royalty (1998), who show that the elements of the individual component may affect the separation probabilities differently for men and for women. For instance, a general finding in these studies is that the presence of children in the household makes women more likely to leave a job, whereas it has the opposite effect on men. ${ }^{15}$

The effect of age on the separation probability is U-shaped for both genders, indicating that young and senior employees are more likely to separate than middle-aged employees. The lowest separation probabilities are found for 44 to 45 year old men and women. Comparing a man aged 30 who has all other characteristics equal to the sample average with a 44-year-old man with similar characteristics reveals a difference in the separation probabilities of 3.7 percentage points. For women the age effect is even more pronounced and the difference is 5.7 percentage points. This shows that the slope of the age profile is relatively steep and has sizeable consequences for the job separation probability. These results are naturally a consequence of senior employee's retirement decisions. For younger employees the argument is more blurred because of the many decisions taking place early in life, such as job shopping, fertility, etc.

Family-related elements, such as marital status and the presence of children in the household, are also found to influence the separation probability significantly. In particular marriage indicates stability, whereas children have opposite effects for men and women. Men tend to become more reluctant to separations, whereas women become more likely to leave the workplace. The difference in separation rates between a married and an unmarried man who have all other characteristics equal to the sample average is three percentage points. Having kids adds an additional percentage point to a man's employment stability. A similar comparison for women shows a marriage gap of 3.5 percentage points and an effect from children of minus 1.5 percentage points.

The education element is also interesting due to the differences in the patterns by gender, but compared to the demographic variables education has relatively little effect on the job separation probability. Nevertheless, education is found to significantly influence the separation probability of women in a U-shaped way, whereas it has an inverted U-shaped effect on the stability of men. The reason for these differences is not obvious, but may be a result of differences in types of educations, i.e., men with little more than 12 years of education are likely to be craftsmen, whereas women with the same level of education may work in clerical jobs.

\footnotetext{
14 These arguments are closely related to the discussion of short and long regressions in Goldberger (1991).

15 These findings are also confirmed by the labor supply literature, in which the effect of children has different implications for participation decisions and hours worked by men and women. See Blundell and MaCurdy (1999) for a recent survey.
} 

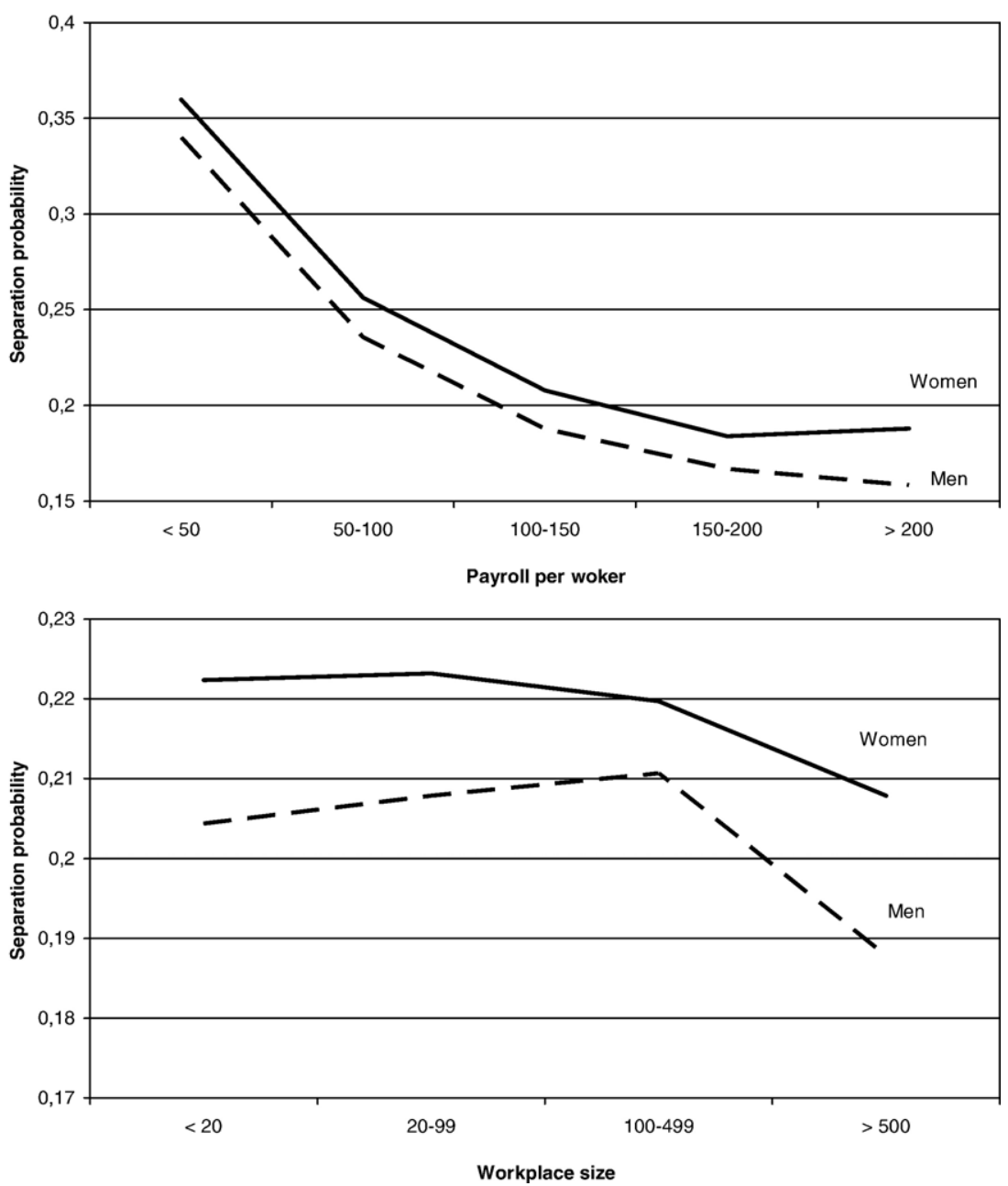

Fig. 2. The effect of payroll per worker and workplace size on the separation probability for an employee with average characteristics.

The models include a dummy indicating if the employee is a newcomer in the workplace (low tenure). The new hire dummy captures the low tenure effect discussed by Farber $(1994,1999)$ and others saying that most jobs end early. This is a result, which is highly supported by the data. Newly recruited men with average characteristics have a 17.5 percentage points higher separation probability than comparable male employees with more tenure. For women the corresponding number is 15 percentage points. One theoretical explanation for this effect is that employees may accept bad matches initially but then keep on searching for better jobs. If better job offers do not arrive fast enough, the employee may have accumulated a sufficiently high level of specific human capital and will stop searching, see Pissarides (1994).

Turning to the effect of workplace characteristics on the separation probability, there are two significant elements to consider: Payroll level and workplace size. The payroll level is found to have a similar effect on the separation probabilities for men and for women as can be seen in 

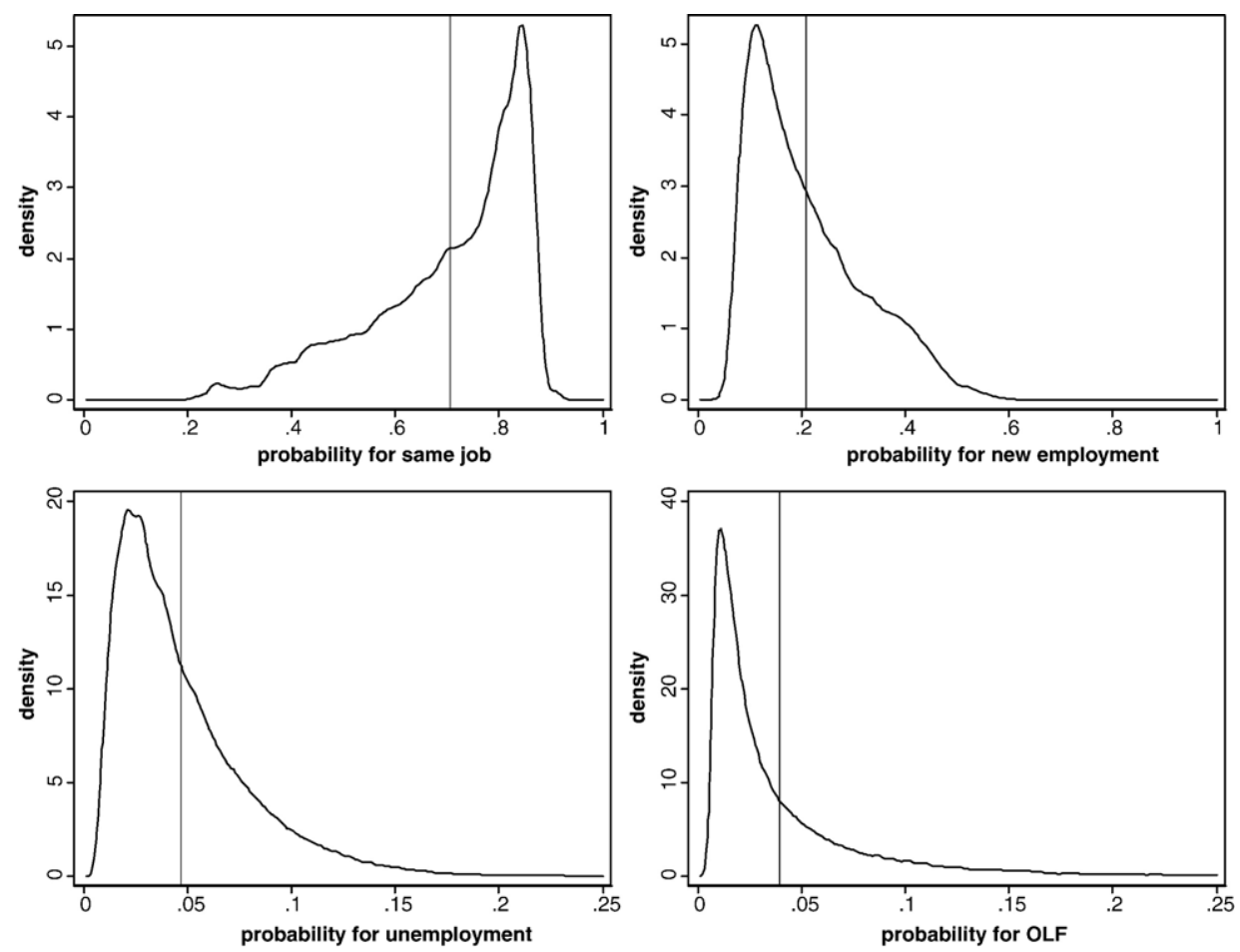

Note: the vertical lines are the means

Fig. 3. Predicted yearly transition densities, all.

Fig. 2. ${ }^{16}$ That is, a higher payroll class reduces the job separation probability significantly. Fig. 2 also shows that the effect of workplace size differs slightly across gender. Size reduces the separation probability monotonically for women but has an inverted U-shaped effect for men. It is the case, however, that the separation probabilities are lowest in large workplaces $(>500$ employees) for both men and women. Interestingly, these findings: the tradeoff between separations and pay together with a lower separation rate in large firms match well with the features of the Burdett-Mortensen model, see Burdett and Mortensen (1998). ${ }^{17}$

In summary, the results presented in this section show that in order to identify potential gender differences in job separation rates, it is important to explicitly address labor market

\footnotetext{
${ }^{16} \mathrm{Oi}$ and Idson (1999) review the literature on workplace size and wages with the intention to explain the positive correlation between the two variables. In the present analysis, I show that both size and wage effects prevail, even after controlling for the individual component. Hence, conditional on the selection on observables the two effects seem to play an independent role in explaining individual job separation behavior.

${ }^{17}$ An alternative explanation given in the literature is that larger workplaces make significant use of internal labor markets (Lazear, 1995; Idson, 1989, 1996). Thus, instead of separating when a particular match should be dissolved, employees are reallocated within the workplace. The benefits from within-workplace reallocations are obvious if specific human capital has been accumulated, Becker (1964). Frederiksen and Westergaard-Nielsen (in press) find empirical evidence, which supports this idea. Complementary to this explanation is that larger workplaces are more capable of fulfilling the employee's career requirements.
} 

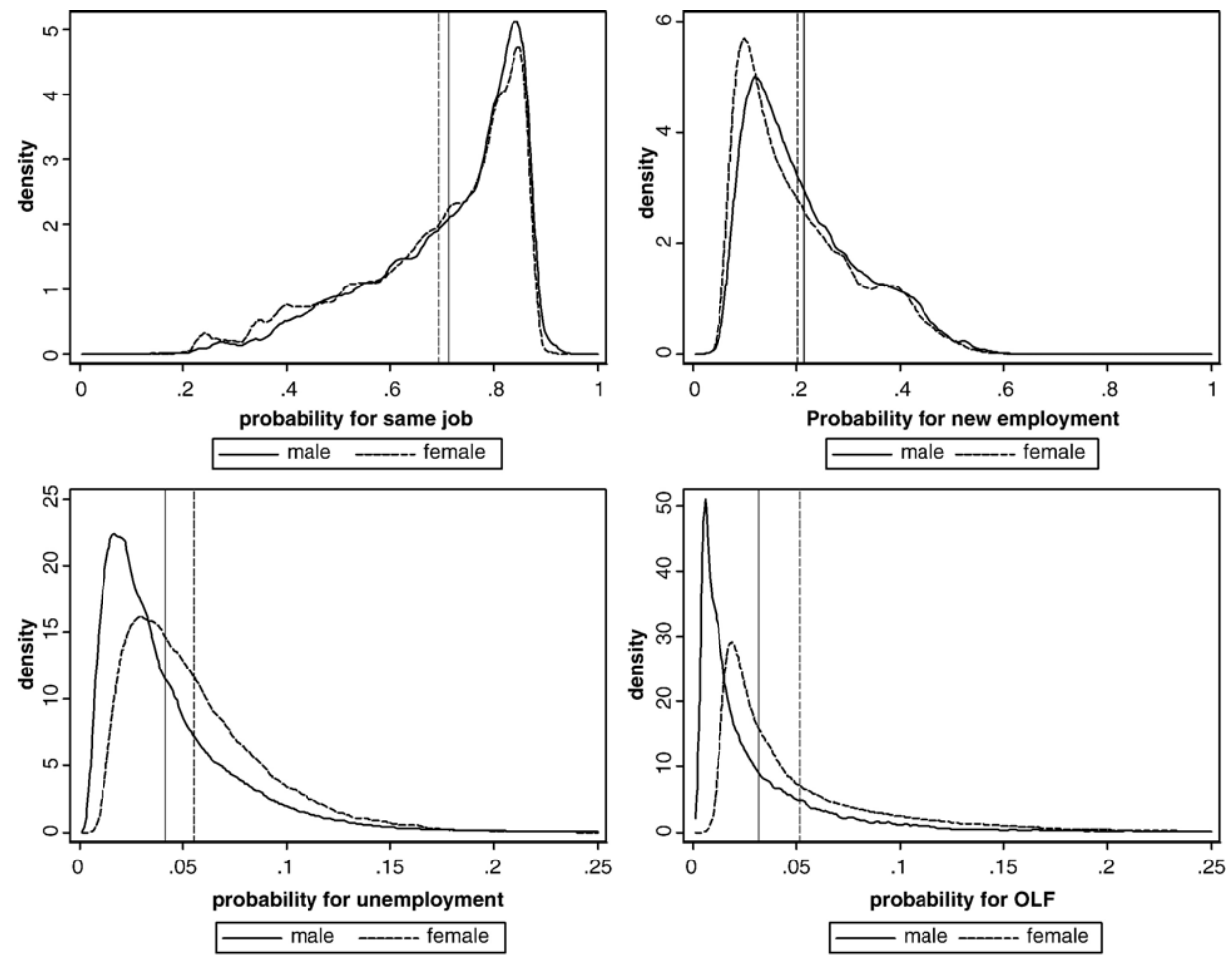

Note: the vertical lines are the means

Fig. 4. Predicted yearly transition densities for men and women.

segregation by considering the effects of the workplace component and the individual component simultaneously. The next section focuses on gender differences in employment stability. For this reason, the analysis of this section will be extended to include information on the destination states following a job separation. Hence, I will turn to estimation of the model outlined in Sections 3 and 4.

\section{Employment stability}

In the section above I concluded that the difference in separation rates between men and women who work in similar workplaces is insignificant. Of course this does not imply that men and women currently working experience the same level of employment stability. They may work in different types of workplaces and may possess different individual characteristics, which influence their likelihood of being employed. The descriptive statistics in section II showed that the average employed woman is slightly younger and less educated than her average male colleague (11.28 vs. 11.84 years of education and 36.01 vs. 36.95 years old). Further, women work in smaller workplaces and in workplaces of a lower payroll class. These differences indicate that women's employment stability may be lower because they posses less attractive match characteristics on average. In order to investigate this issue further, I estimate the multinomial logit model presented in Section 4 with the four states: 'stay in the same job', new employment, 
Table 4

Predicted yearly transition probabilities

\begin{tabular}{lrrr}
\hline & Women & Men & $\begin{array}{c}\text { Women with men's } \\
\text { characteristics }\end{array}$ \\
\hline Same job & 69.226 & 71.263 & 71.304 \\
New employment & 20.096 & 21.431 & 18.873 \\
Unemployment & 5.540 & 4.135 & 5.181 \\
Out of the labor force & 5.139 & 3.171 & 4.642 \\
Employment probability & 89.322 & 92.694 & 90.177 \\
\hline
\end{tabular}

unemployment, and 'out of the labor force' (OLF). The detailed results are shown in Appendix B1. ${ }^{18}$

The point estimates from a multinomial logit model are difficult to interpret. For this reason the estimated parameters are used to predict the probability of making transitions from the current job into each of the four states for all individuals in the sample. The predicted values are plotted in Fig. 3 using kernel techniques. From the graph in the upper left corner it can be seen that most individuals are placed in stable employment matches. Thus, the probability of staying with the current employer clearly dominates all other transitions. For some individuals, however, the separation probability is large (one minus the probability of staying in the same workplace), which is reflected in the other graphs presented in Fig. 3. In particular job-to-job transitions play an important role in the labor market, and some individuals have almost a 50 percent chance of making such a move. The non-employment states, i.e., unemployment and OLF, play a much smaller role in the economy (note the scale differences in the graphs). On average, currently employed individuals face an unemployment risk of only 5 percent. The figures also suggest that withdrawals from the labor market are unlikely to happen for the majority of individuals. ${ }^{19}$

The gender issue is addressed in Fig. 4 where kernels based on separate estimations for women and men are presented. ${ }^{20}$ The average retention probabilities for women and men are 69 and 71 percent, respectively; indicating that women are more likely to leave their current job. This result was expected due to the discussion of labor market sorting and the documented differences in individual and workplace components. In addition to the lower retention probability, currently employed women are less likely to make job-to-job transitions and more likely to become unemployed or leave the labor force. These results clearly show that women relative to men experience lower employment stability.

\section{Discussion of economic policy}

The presented analysis provides some scope for economic policy recommendations. These are derived from a standard Oaxaca-Blinder decomposition, which is a methodology traditionally applied to decompose the gender wage gap into a part explained by gender differences in endowments (observable characteristics) and a part explained by gender differences in "prices",

\footnotetext{
${ }^{18}$ Due to burdensome computations, the data used in the estimation are limited to a random sample of 10 percent of the individual employment histories registered in the IDA database. Because the number of observations in the regression is still above 2.6 million, this reduction does not induce any loss of generality.

19 See Appendix C for descriptive statistics on the predicted probabilities.

20 These regressions are presented in Appendices B2 and B3, and descriptive statistics for the predictions can be found in Appendix C.
} 


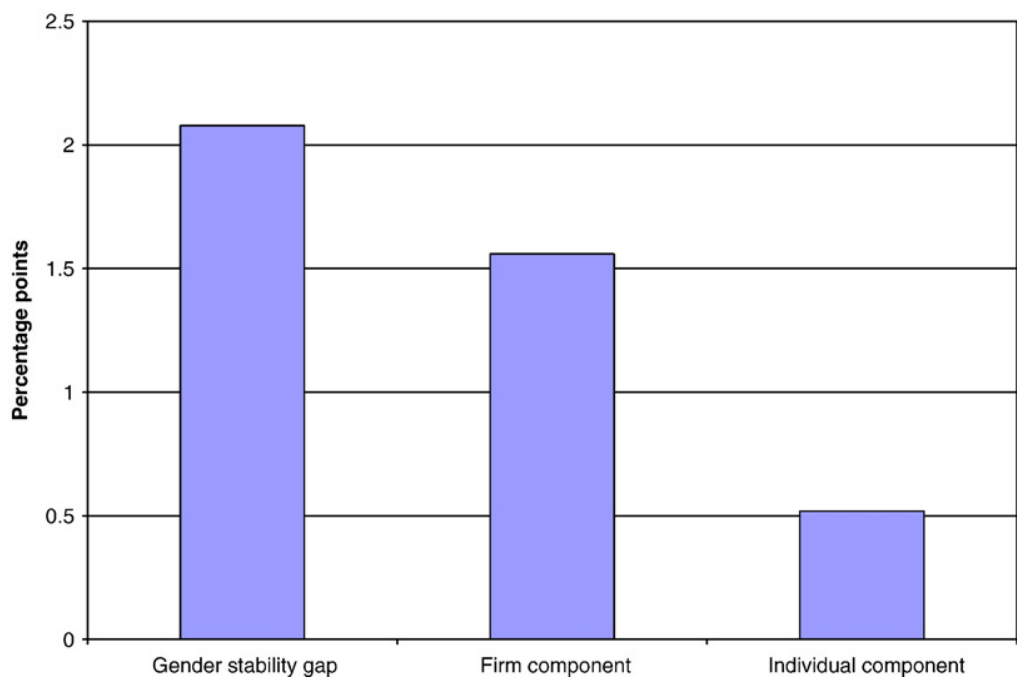

Fig. 5. Gender stability gap decomposition.

i.e. the estimated parameters. Using this method to decomposition the employment stability gap provides important insights into the reasons for women's lower employment stability and where future policies should be targeted (see Appendix D for details). ${ }^{21}$

The gender decomposition is conducted by using the individual behavior observed in the labor market, given the empirical distribution of employees across firms, to obtain point estimates of the "prices" in the market. Subsequently, responses in the mobility patterns to changes in women's characteristics, given fixed "prices", are simulated to see how economic policies may affect employment stability and mobility. The simulation naturally relies on the assumption that there are no feedback effects on the models parameters due to changes in the employee's human capital etc. ${ }^{22}$ For instance exogenously changing an employee's education will make the individual behave as the group empirically observed with that education. Similarly, exogenously moving a woman from a small low-wage workplace to a larger high-wage workplace will make her adopt the behavior of women empirically observed in the larger workplace. For small changes in the observable characteristics this assumption may not be critical. ${ }^{23}$

The first two columns of Table 4 present the predicted average transition probabilities for each of the four destinations states by gender. These numbers are obtained from separate regression of men and women. The last column shows the predicted transition probabilities in the case where the women's sample has been adjusted to match the average characteristics of men, i.e., same age, education level, payroll class, etc., but the estimated parameters remain the same as in the first column. This leads to an interesting result: the retention probabilities equalize, but women's lower employment stability prevails because they continue to have more frequent transitions into unemployment and out of the labor force.

The question that remains to be answered is to what extent the difference in the retention rates between men and women is driven by the individual or workplace component. Fig. 5 presents the

\footnotetext{
${ }^{21}$ Note that the predictions are made from a nonlinear model; hence, the predicted probabilities are sensitive to the transformation made. This is not the case for the linear model (Blinder, 1973; Oaxaca, 1973).

22 This assumption is standard in the literature; see for instance the discussion by Gupta, Oaxaca and Smith (2006).

23 Relaxing this assumption requires an explicit modeling of the underlying reasons for the empirically observed gender segregation and how it is related to market "prices". This is, however, beyond the scope of this paper.
} 
decomposition. ${ }^{24}$ The first column illustrates the total gap of two percentage points. The second and third columns show how big a proportion of the gap is explained by the workplace and individual components, respectively. These results reveal that if women had an individual component similar to that of men, their retention probability would increase by 0.5 percentage points, corresponding to 25 percent of the initial gap. The workplace component seems to be much more important and changing women's workplace component to match that of men's increases job stability by 1.5 percentage points, or 75 percent of the initial gap.

The results from the decomposition show that, given the imposed assumption of no feedback in the parameters, the retention rates between men and women equalize when they have similar characteristics. Based on this finding, any policy capable of making women's observable characteristics more like those of men will increase women's retention rates. Unfortunately, the simulation also shows that even when all observable differences are eliminated, women continue to have more transitions into non-employment. This suggests that a combination of "discrimination" and differences in preferences continue to produce a gender gap in employment stability which will be difficult to remove for policy makers.

Within this setting, concrete examples of economic policy that reduce the employment stability gap involve educational and child policies. For instance, the presented results show that employees with certain levels of education have lower job separation rates. Thus, it seems natural to argue for an economic policy, which provides incentives for low- or non-educated women to pursue "high-stability educations". Another example is that children in the household increase a woman's probability of leaving work. This suggests that child policies improving women's job attachment after childbirth continue to be highly relevant - even in a country such as Denmark, which has relatively developed and flexible maternity leave programs and an extensive and heavily subsidized childcare system.

\section{Conclusion}

In this paper, I have studied the job separation process to learn about gender differences in job separation probabilities and employment stability. In contrast to earlier studies, which have focused on the importance of either individual or workplace characteristics, I use employeremployee data to obtain a series of new empirical results.

The main finding in this paper is that there is no significant difference in job separation probabilities between men and women with similar characteristics working in similar workplaces. This is an important result because employers are concerned about the costs imposed by job separations. Therefore, even small differences in the expected likelihood of job separations across gender would lead to statistical discrimination. Given there are no systematic differences due to gender, these concerns should no longer be present. Hence, the observed segregation of men and women into different types of workplaces should not be due to statistical discrimination related to job separation decisions.

A second important finding is that women currently working in the labor market experience relatively low employment stability. There are two reasons for this. First, men and women are to some extent segregated in the labor market, i.e., women tend to work in smaller low-wage workplaces with relatively low retention probabilities. Further, women have individual characteristics that are associated with relatively high job separation rates. Therefore, they

\footnotetext{
${ }^{24}$ The predicted probabilities can be seen in Appendix D.
} 
experience job separations more frequently. Second, women have more transitions out of the labor market and into unemployment and make fewer job-to-job transitions.

The analysis provides some scope for economic policy targeting gender equality in employment stability. For instance, policies eliminating the gender differences in observable individual and workplace characteristics may reduce the stability gap. Such policies include improvements of women's human capital accumulation and better childcare.

Finally, this paper expands on previous research. For this reason, the analysis has deliberately been constrained, such that it clearly illustrates the information advantage of employer-employee data over previous studies focusing on either individual or workplace characteristics. This implies that additional studies of the job separation process and employment stability are warranted. For instance, the effect of individual wages on the job separation process remains to be established. It would also be interesting to understand the consequences of the revealed heterogeneity in job separation rates across both individuals and firms on investments in human capital. Thus, in addition to presenting a series of new empirical results, this study paves the way for future research.

\section{Appendix A. An international comparison. ${ }^{25}$}

Denmark provides an interesting test site for studies of the job separation process because the interference in the labor market from the legal and bureaucratic systems is relatively low. According to $\operatorname{OECD}(1996,1997)$, the Danish labor market was rated almost as liberal as the US labor market and on the same level as Switzerland and the United Kingdom.

In contrast to most other continental European countries, a blue-collar employee in Denmark can be laid off with very short notice and almost without any cost. ${ }^{26}$ Since 1989 , employers have had to pay for the first day of unemployment (extended to two days from 1992); but besides that, there is no experience rating or redundancy payment. For most white-collar employees, rules require a layoff notice of about one month for each year the individual has been employed, up to a certain maximum. Thus, it is less costly to fire employees in Denmark compared to the United States where employer contributions to the UI-system are a function of their past record (experience rated system). Furthermore, social contributions, pension, vacation pay and health insurance follow the employee and are independent of the employer.

The main difference between employees in the US or the UK and Denmark is that a Danish employee is eligible to relatively high UI-benefits and for a long period (four years in 2001 but up to nine in the investigated period). The taxable benefits are 90 percent of the previous wage, up to a maximum. This has the implication that only 10 percent of all insured men and about 35 percent of all insured women are on the 90 percent interval. Unemployment benefits are easily obtainable for members of the unemployment benefit system with no waiting period when laid off but with a 5-week waiting period after a quit.

In the private sector, wages are determined at the establishment level under strong influence of unions. This implies that wage dispersion is relatively compressed at the establishment level but not as much between establishments. In order to break the compressed wage structure, employees will have to move to another establishment where the wage level is higher. Seniority-based payment systems are not common in the private sector. Finally, Denmark has few large workplaces or establishments, meaning that internal labor markets play a minor role.

\footnotetext{
25 Recent surveys over the Danish labor market policies can be found in De Koning et al. (2002) and WestergaardNielsen (2001).

${ }^{26}$ Although there is no statutory job protection for blue-collar employees, some groups have the right to notice prior to layoff (two weeks).
} 
Appendix B

Multinomial logit model, pooled

\begin{tabular}{|c|c|c|c|}
\hline & Re-employment & Unemployment & Out of labor force \\
\hline \multicolumn{4}{|l|}{ Individual characteristics } \\
\hline Women & $\begin{array}{c}-0.136 \\
(0.004)\end{array}$ & $\begin{array}{l}0.298 \\
(0.007)\end{array}$ & $\begin{array}{l}0.392 \\
(0.007)\end{array}$ \\
\hline Age/10 & $\begin{array}{l}-0.587 \\
(0.011)\end{array}$ & $\begin{array}{l}0.040 \\
(0.019)\end{array}$ & $\begin{array}{l}-3.543 \\
(0.020)\end{array}$ \\
\hline Age squared/100 & $\begin{array}{l}0.035 \\
(0.001)\end{array}$ & $\begin{array}{l}-0.006 \\
(0.002)\end{array}$ & $\begin{array}{l}0.463 \\
(0.002)\end{array}$ \\
\hline Married & $\begin{array}{l}-0.103 \\
(0.004)\end{array}$ & $\begin{array}{l}-0.384 \\
(0.008)\end{array}$ & $\begin{array}{l}-0.312 \\
(0.009)\end{array}$ \\
\hline Children & $\begin{array}{l}-0.053 \\
(0.004)\end{array}$ & $\begin{array}{l}-0.111 \\
(0.008)\end{array}$ & $\begin{array}{l}-0.046 \\
(0.010)\end{array}$ \\
\hline Education $<12$ years & - & - & - \\
\hline Education $12-16$ years & $\begin{array}{l}0.080 \\
(0.004)\end{array}$ & $\begin{array}{l}-0.410 \\
(0.007)\end{array}$ & $\begin{array}{l}-0.051 \\
(0.007)\end{array}$ \\
\hline Education $>16$ years & $\begin{array}{l}0.150 \\
(0.009)\end{array}$ & $\begin{array}{l}-0.687 \\
(0.021)\end{array}$ & $\begin{array}{l}-0.533 \\
(0.024)\end{array}$ \\
\hline New hire dummy (tenure $<2$ years) & $\begin{array}{l}0.788 \\
(0.006)\end{array}$ & $\begin{array}{l}0.960 \\
(0.006)\end{array}$ & $\begin{array}{l}0.807 \\
(0.007)\end{array}$ \\
\hline \multicolumn{4}{|l|}{ Workplace characteristics } \\
\hline Payroll < DKK 50 thousand & - & - & - \\
\hline Payroll DKK 50-100 thousand & $\begin{array}{l}-0.488 \\
(0.007)\end{array}$ & $\begin{array}{l}-0.366 \\
(0.011)\end{array}$ & $\begin{array}{l}-0.715 \\
(0.011)\end{array}$ \\
\hline Payroll DKK 100-150 thousand & $\begin{array}{l}-0.749 \\
(0.007)\end{array}$ & $\begin{array}{l}-0.737 \\
(0.012)\end{array}$ & $\begin{array}{l}-1.038 \\
(0.012)\end{array}$ \\
\hline Payroll DKK 150-200 thousand & $\begin{array}{l}-0.870 \\
(0.007)\end{array}$ & $\begin{array}{l}-1.018 \\
(0.013)\end{array}$ & $\begin{array}{l}-1.161 \\
(0.013)\end{array}$ \\
\hline Payroll > DKK 200 thousand & $\begin{array}{l}-1.503 \\
(0.007)\end{array}$ & $\begin{array}{l}-1.328 \\
(0.014)\end{array}$ & $\begin{array}{l}-1.296 \\
(0.014)\end{array}$ \\
\hline Workplace size $<20$ employees & - & - & - \\
\hline Workplace size 20-99 employees & $\begin{array}{l}0.016 \\
(0.004)\end{array}$ & $\begin{array}{c}-0.034 \\
(0.008)\end{array}$ & $\begin{array}{l}0.076 \\
(0.008)\end{array}$ \\
\hline Workplace size 100-499 employees & $\begin{array}{l}0.010 \\
(0.005)\end{array}$ & $\begin{array}{l}-0.038 \\
(0.009)\end{array}$ & $\begin{array}{l}0.160 \\
(0.010)\end{array}$ \\
\hline Workplace size $>500$ employees & $\begin{array}{l}-0.127 \\
(0.006)\end{array}$ & $\begin{array}{l}-0.167 \\
(0.012)\end{array}$ & $\begin{array}{l}0.160 \\
(0.013)\end{array}$ \\
\hline Unemployment rate controls & Yes & Yes & Yes \\
\hline Industry controls & Yes & Yes & Yes \\
\hline
\end{tabular}

Note: The estimation is made on a 10 percent random sample of individual employment histories. Number of observations: $2,613,454$. The reference category is "stay with same employer".

Appendix B.1

Multinomial logit model, women

\begin{tabular}{llcc}
\hline & Re-employment & Unemployment & Out of labor force \\
\hline Individual characteristics & & & -3.616 \\
Age/10 & -0.715 & -0.680 & $(0.030)$ \\
\hline
\end{tabular}


Appendix B.1 (continued)

\begin{tabular}{|c|c|c|c|}
\hline & Re-employment & Unemployment & Out of labor force \\
\hline \multicolumn{4}{|l|}{ Individual characteristics } \\
\hline Age squared/100 & $\begin{array}{l}0.047 \\
(0.003)\end{array}$ & $\begin{array}{l}0.074 \\
(0.004)\end{array}$ & $\begin{array}{l}0.460 \\
(0.004)\end{array}$ \\
\hline Married & $\begin{array}{l}-0.167 \\
(0.007)\end{array}$ & $\begin{array}{c}-0.228 \\
(0.011)\end{array}$ & $\begin{array}{l}-0.222 \\
(0.013)\end{array}$ \\
\hline Children & $\begin{array}{l}-0.081 \\
(0.007)\end{array}$ & $\begin{array}{l}0.214 \\
(0.012)\end{array}$ & $\begin{array}{l}0.258 \\
(0.014)\end{array}$ \\
\hline Education $<12$ years & - & - & - \\
\hline Education $12-16$ years & $\begin{array}{l}0.050 \\
(0.006)\end{array}$ & $\begin{array}{l}-0.385 \\
(0.010)\end{array}$ & $\begin{array}{l}-0.078 \\
(0.010)\end{array}$ \\
\hline Education $>16$ years & $\begin{array}{l}0.155 \\
(0.014)\end{array}$ & $\begin{array}{l}-0.563 \\
(0.031)\end{array}$ & $\begin{array}{l}-0.352 \\
(0.033)\end{array}$ \\
\hline New hire dummy (tenure $<2$ years) & $\begin{array}{l}0.728 \\
(0.006)\end{array}$ & $\begin{array}{l}0.789 \\
(0.009)\end{array}$ & $\begin{array}{l}0.696 \\
(0.010)\end{array}$ \\
\hline \multicolumn{4}{|l|}{ Workplace characteristics } \\
\hline Payroll $<$ DKK 50 thousand & - & - & - \\
\hline Payroll DKK 50-100 thousand & $\begin{array}{l}-0.491 \\
(0.009)\end{array}$ & $\begin{array}{l}-0.307 \\
(0.015)\end{array}$ & $\begin{array}{l}-0.683 \\
(0.015)\end{array}$ \\
\hline Payroll DKK 100-150 thousand & $\begin{array}{l}-0.760 \\
(0.010)\end{array}$ & $\begin{array}{l}-0.626 \\
(0.016)\end{array}$ & $\begin{array}{l}-0.947 \\
(0.016)\end{array}$ \\
\hline Payroll DKK 150-200 thousand & $\begin{array}{l}-0.889 \\
(0.011)\end{array}$ & $\begin{array}{l}-0.879 \\
(0.019)\end{array}$ & $\begin{array}{l}-1.082 \\
(0.019)\end{array}$ \\
\hline Payroll > DKK 200 thousand & $\begin{array}{l}-0.791 \\
(0.012)\end{array}$ & $\begin{array}{l}-1.095 \\
(0.022)\end{array}$ & $\begin{array}{l}-1.165 \\
(0.021)\end{array}$ \\
\hline Workplace size $<20$ employees & - & - & - \\
\hline Workplace size 20-99 employees & $\begin{array}{l}-0.048 \\
(0.007)\end{array}$ & $\begin{array}{l}-0.040 \\
(0.011)\end{array}$ & $\begin{array}{l}0.086 \\
(0.012)\end{array}$ \\
\hline Workplace size 100-499 employees & $\begin{array}{l}-0.034 \\
(0.008)\end{array}$ & $\begin{array}{l}-0.065 \\
(0.014)\end{array}$ & $\begin{array}{l}0.114 \\
(0.014)\end{array}$ \\
\hline Workplace size $>500$ employees & $\begin{array}{l}-0.074 \\
(0.011)\end{array}$ & $\begin{array}{l}-0.260 \\
(0.019)\end{array}$ & $\begin{array}{l}0.091 \\
(0.019)\end{array}$ \\
\hline Unemployment rate controls & Yes & Yes & Yes \\
\hline Industry controls & Yes & Yes & Yes \\
\hline
\end{tabular}

Note: The estimation is made on a 10 percent random sample of individual employment histories. The reference category is "stay with same employer".

Appendix B.2

Multinomial logit model, men

\begin{tabular}{llll}
\hline & Re-employment & Unemployment & Out of labor force \\
\hline Individual characteristics & & & -3.422 \\
Age/10 & -0.460 & 0.462 & $(0.026)$ \\
& $(0.014)$ & $(0.025)$ & 0.461 \\
Age squared/100 & 0.021 & -0.050 & $(0.003)$ \\
Married & $(0.002)$ & $(0.003)$ & -0.467 \\
& -0.066 & -0.481 & $(0.014)$ \\
Children & $(0.006)$ & $(0.011)$ & -0.474 \\
& -0.051 & -0.375 & $(0.016)$ \\
\hline
\end{tabular}


Appendix B.2 (continued)

\begin{tabular}{|c|c|c|c|}
\hline & Re-employment & Unemployment & Out of labor force \\
\hline \multicolumn{4}{|l|}{ Individual characteristics } \\
\hline Education $<12$ years & - & - & - \\
\hline \multirow[t]{2}{*}{ Education $12-16$ years } & 0.082 & -0.428 & -0.0472 \\
\hline & $(0.005)$ & $(0.009)$ & $(0.010)$ \\
\hline \multirow[t]{2}{*}{ Education $>16$ years } & 0.138 & -0.814 & -0.776 \\
\hline & $(0.010)$ & $(0.030)$ & $(0.035)$ \\
\hline \multirow[t]{2}{*}{ New hire dummy (tenure $<2$ years) } & 0.818 & 1.076 & 0.891 \\
\hline & $(0.004)$ & $(0.008)$ & $(0.010)$ \\
\hline \multicolumn{4}{|l|}{ Workplace characteristics } \\
\hline Payroll $<$ DKK 50 thousand & - & - & - \\
\hline \multirow[t]{2}{*}{ Payroll DKK 50-100 thousand } & -0.485 & -0.437 & -0.770 \\
\hline & $(0.010)$ & $(0.017)$ & $(0.018)$ \\
\hline \multirow[t]{2}{*}{ Payroll DKK 100-150 thousand } & -0.742 & -0.838 & -1.145 \\
\hline & $(0.010)$ & $(0.017)$ & $(0.018)$ \\
\hline \multirow[t]{2}{*}{ Payroll DKK 150-200 thousand } & -0.862 & -1.123 & -1.125 \\
\hline & $(0.010)$ & $(0.018)$ & $(0.019)$ \\
\hline \multirow[t]{2}{*}{ Payroll > DKK 200 thousand } & -0.863 & -1.496 & -1.431 \\
\hline & $(0.014)$ & $(0.020)$ & $(0.021)$ \\
\hline Workplace size $<20$ employees & - & - & - \\
\hline \multirow[t]{2}{*}{ Workplace size 20-99 employees } & 0.027 & -0.037 & 0.056 \\
\hline & $(0.005)$ & $(0.010)$ & $(0.012)$ \\
\hline \multirow[t]{2}{*}{ Workplace size 100-499 employees } & 0.031 & -0.028 & 0.189 \\
\hline & $(0.006)$ & $(0.013)$ & $(0.015)$ \\
\hline \multirow[t]{2}{*}{ Workplace size $>500$ employees } & 0.155 & -0.098 & 0.225 \\
\hline & $(0.008)$ & $(0.016)$ & $(0.017)$ \\
\hline Unemployment rate controls & Yes & Yes & Yes \\
\hline Industry controls & Yes & Yes & Yes \\
\hline
\end{tabular}

Note: The estimation is made on a 10 percent random sample of individual employment histories. The reference category is "stay with same employer".

Appendix C

Descriptive statistics for the predicted probabilities

\begin{tabular}{|c|c|c|c|c|}
\hline & Mean & Std. dev. & Minimum & Maximum \\
\hline \multicolumn{5}{|l|}{ All employees } \\
\hline Same job & 0.705 & 0.148 & 0.122 & 0.928 \\
\hline New employment & 0.209 & 0.109 & 0.029 & 0.639 \\
\hline Unemployment & 0.047 & 0.031 & 0.004 & 0.309 \\
\hline Out of labor force & 0.039 & 0.046 & 0.003 & 0.786 \\
\hline \multicolumn{5}{|l|}{ Female employees } \\
\hline Same job & 0.692 & 0.155 & 0.188 & 0.909 \\
\hline New employment & 0.201 & 0.110 & 0.033 & 0.611 \\
\hline Unemployment & 0.055 & 0.032 & 0.007 & 0.255 \\
\hline Out of labor force & 0.051 & 0.048 & 0.006 & 0.685 \\
\hline \multicolumn{5}{|l|}{ Male employees } \\
\hline Same job & 0.712 & 0.143 & 0.102 & 0.937 \\
\hline New employment & 0.214 & 0.109 & 0.030 & 0.635 \\
\hline Unemployment & 0.041 & 0.032 & 0.002 & 0.342 \\
\hline Out of labor force & 0.032 & 0.043 & 0.001 & 0.798 \\
\hline
\end{tabular}


Appendix D

Stability gap decomposition

\begin{tabular}{lllll}
\hline & Same job & New employment & Unemployment & Out of the labor force \\
\hline Women: $\beta_{j W}, \gamma_{j W}, X_{W}, Z_{W}$ & 69.226 & 20.096 & 5.540 & 5.139 \\
Men: $\beta_{j M}, \gamma_{j M}, X_{M}, Z_{M}$ & 71.263 & 21.431 & 4.135 & 3.171 \\
Decomposition: & & & & 5.025 \\
$\beta_{j W}, \gamma_{j W}, \tilde{X} w, Z_{W}$ & 69.745 & 19.727 & 5.550 & 4.749 \\
$\beta_{j W}, \gamma_{j W}, X_{W}, \tilde{Z} w$ & 70.785 & 19.245 & 5.220 & 4.642 \\
$\beta_{j W}, \gamma_{j W}, \tilde{X} w, \tilde{Z}_{w}$ & 71.304 & 18.873 & 5.181 & 3.370 \\
$\beta_{j M}, \gamma_{j M}, X_{W}, Z_{W}$ & 69.485 & 22.655 & 4.449 & \\
\hline
\end{tabular}

Note: $\tilde{X} w=X_{W}+\left(E X_{M}-E X_{W}\right)$ and $\tilde{Z} w=Z_{W}+\left(E Z_{M}-E Z_{W}\right)$, where $\mathrm{W}$ and $\mathrm{M}$ indicate women and men, respectively.

\section{References}

Anderson, Patricia M., Meyer, Bruce D., 1994. The Extent and Consequences of Job Turnover. Brookings Papers on Economic Activity: Microeconomics 177-248.

Bayard, Kimberly, Hellerstein, Judith, Numark, David, Troske, Ken, 2003. New Evidence on Sex Segregation and Sex Differences in Wages from Matched Employee-Employer Data. Journal of Labor Economics 21, 887-922.

Becker, Gary S., 1964. Human Capital1st ed. The National Bureau of Economic Research, New York.

Blau, Francine D., Kahn, Lawrence M., 1981. Race and Sex Differences in Quits by Young Workers. Industrial and Labor Relations Review 34, 563-577.

Blinder, Allan S., 1973. Wage Discrimination: Reduced Form and Structural Variables. Journal of Human Resources 8, 436-455.

Blundell, Richard, MaCurdy, Tom, 1999. Labor Supply: a Review of Alternative Approaches. In: Ashenfelter, O., Card, D. (Eds.), The Handbook of Labor Economics, vol. 3. Elsevier Science B.V.

Burdett, Kenneth, Mortensen, Dale T., 1998. Wage Differentials, Employer Size, and Unemployment. International Economic Review 39, 257-273.

Davis, Steven J., Haltiwanger, John, 1999. Gross Job Flows. In: Ashenfelter, O., Card, D. (Eds.), The Handbook of Labor Economics, vol. 3. Elsevier Science B.V.

Davis, Steven J., Haltiwanger, John, Schuh, Scott, 1996. Job Creation and Destruction. MIT Press, Cambridge, MA.

De Koning, Jaap, Layard, Richard, Nickell, Stephen, Westergaard-Nielsen, Niels, 2002. Policies for Full Employment.

Farber, Henry S., 1994. The Analysis of Interfirm Worker Mobility. Journal of Labor Economics 12, 554-593.

Farber, Henry S., 1999. Mobility and Stability: The Dynamics of Job Change in Labor Markets. In: Ashenfelter, O., Card, D. (Eds.), The Handbook of Labor Economics, vol. 3. Elsevier Science B.V.

Frederiksen, Anders, Takàts, Elöd, 2006. Layoffs as Part of an Optimal Incentive Mix: Theory and Evidence. IZA Discussion Paper, vol. 2447.

Frederiksen, Anders, Westergaard-Nielsen, Niels, in press. Where did they go? Modelling Transitions Out of Jobs. Labour Economics (Available online 28 November 2006).

Frederiksen, Anders, Honoré, Bo E., Hu, Luojia, in press. Discrete time duration models with group-level heterogeneity. Journal of Econometrics (Available online 7 February 2007).

Goldberger, Arthur S., 1991. A Course in Econometrics. Harvard University Press, Cambridge, MA.

Gupta, Nabanita D., 1993. Probabilities of Job Choice and Employer Selection and Male-Female Occupational Differences. American Economic Review Paper and Proceedings, vol. 83, pp. 75-79.

Gupta, Nabanita D., Oaxaca, Ronald L., Smith, Nina, 2006. Swimming Upstream, Floating Downstream: Comparing Women's Relative Wage Progress in the United States and Denmark, vol. 59, pp. 243-266.

Holmström, Bengt, 1979. Moral Hazard and Observability. Bell Journal of Economics 9, 74-91.

Idson, Todd L., 1989. Establishment Size Differentials in Internal Mobility. The Review of Economics and Statistics 71, $721-724$.

Idson, Todd L., 1996. Employer Size and Labor Turnover. In: Polachek, S.W. (Ed.), Research in Labor Economics, vol. 15. Jovanovic, Boyan, 1979. Job Matching and the Theory of Turnover. Journal of Political Economy 87, 972-990.

Lazear, Edward P., 1995. Personnel Economics. The MIT Press, Cambridge, MA.

Light, Audrey, Ureta, Manuelita, 1992. Panel Estimates of Male and Female Job Turnover Behaviour: Can Female Nonquitters Be Identified? Journal of Labor Economics 10, 156-181. 
Lynch, Lisa M., 1992. Differential Effects of Post-school Training on Early Career Mobility. Working Paper. National Bureau of Economic Research.

Macpherson, David A., Hirsch, Barry T., 1995. Wages and Gender Composition: Why do Women's Jobs Pay Less. Journal of Labor Economics 13, 426-471.

Oaxaca, Ronald, 1973. Male-Female Wage Differentials in Urban Labor Markets. International Economic Review 14, 693-709.

OECD, 1996. Employment Outlook.

OECD, 1997. Employment Outlook.

Oi, Walter Y., Idson, Todd L., 1999. Firm Size and Wages. In: Ashenfelter, O., Card, D. (Eds.), The Handbook of Labor Economics, vol. 3. Elsevier Science B.V.

Royalty, Anne B., 1998. Job-to-Job and Job-to-Nonemployment Turnover by Gender and Education Level. Journal of Labor Economics 14, 392-443.

Padavic, Irene, 1992. White-Collar Work Values and Women's Interest in Blue-Collar Jobs. Gender and Society 6, $215-230$.

Pissarides, Christopher A., 1994. Search Unemployment with On-the-job Search. The Review of Economic Studies 61, $457-475$.

Sicherman, Nachum, 1996. Gender Differences in Departures from a Large Firm. Industrial and Labor Relations Review 49, 484-505.

Spence, Michael A., 1973. Job Market Signaling. The Quarterly Journal of Economics 87, 355-374.

Weiss, Andrew, 1984. Determinants of Quit Behaviour. Journal of Labor Economics 2, 371-387.

Westergaard-Nielsen, Niels, 2001. 20 Years of Labor Market Policies in Denmark. In: Ilmakunnas, S. (Ed.), Labor Institutions and Employment. The Government Institute for Economic Research, Helsinki, Finland. 